\title{
CARTA DOS EDITORES
}

Novos ares sopram na revista temáticas! A edição de número 52 da revista de pós-graduandos em ciências sociais do IFCH - UNICAMP traz consigo não apenas um novo dossiê, brindando a tradição do periódico; como também, a marca de uma nova gestão editorial, voluntária e coletiva, que angaria esforços desde o primeiro semestre de 2017.

Naquela ocasião, o atual grupo de editores se reuniu para dar início ao processo de reestruturação da revista, que compreendia a renovação do Conselho Editorial; a adequação dos critérios de publicação da revista para indexação em portais de divulgação científica (tarefa que está sendo realizada com êxito); o aprimoramento do processo de recebimento e seleção de artigos; a adoção da Plataforma OJS; e a seleção pública de novos dossiês - entre eles, o dossiê "Economia Feminista", apresentado nesta edição ${ }^{1}$. Tudo isto para tornar a temáticas uma revista mais forte no cenário da divulgação científica especializada em ciências sociais sem, no entanto, perder seu caráter de periódico criado para veiculação da produção discente de pós-graduação do país (mas não só).

Nesse mesmo período de tempo, conseguimos reestabelecer a periodicidade da revista, fazendo com que, em 2018, fossem publicados os dossiês referentes aos anos de $2016^{2}$ e $2017^{3}$, e os dois números do ano. Conseguimos também reunir - por duas vezes, e em volumes cada vez maiores - propostas de pesquisadores interessados em publicar seus dossiês nesta revista. Assim, o primeiro processo de seleção pública de dossiês rendeu os dois volumes do ano de 2018 e o primeiro do ano de

\footnotetext{
${ }^{1}$ Os outros dossiês são: "Infâncias rurais: diálogos interdisciplinares" (n. 51, publicado em 2018) e "O Ciclo Petista: reflexões a partir das ciências sociais" (n. 53, em preparação para ser publicado ainda no primeiro semestre de 2019).

2 "Entre greves, ocupações e golpes: o Brasil de 2016" (Temáticas, n. 47/48).

3 "Dinâmicas migratórias haitianas no Brasil: desafios e contribuições" (Temáticas, n. 49/50).
} 
2019. Já a segunda seleção nos trouxe os dossiês que serão publicados no segundo semestre de $2019^{4}$ e nos dois de $2020^{5}$. Mudanças tímidas, mas que refletem o novo comprometimento do trabalho coletivo discente realizado não apenas pelos membros do comitê editorial da temáticas, como por todas e todos aqueles que, de alguma forma, acreditam na revista autores, organizadores de dossiê, pareceristas, trabalhadores técnicos e administrativos (a quem devemos agradecimentos públicos).

Esperamos que os/as leitores possam aproveitar essa nova fase. Que os novos ares continuem e que possam nos brindar ainda mais com melhorias e novidades.

Os/as editores/as.

4 "A Construção Social do Ódio" (Temáticas, n. 54).

5 "Práticas médicas e terapêuticas na América" (Temáticas, n. 55, $1^{\circ}$ semestre de 2020) e "Militares em Perspectiva" (Temáticas, n. 56, 20 semestre de 2020). 